GEOLOGICAL SURVEY CIRCULAR 236

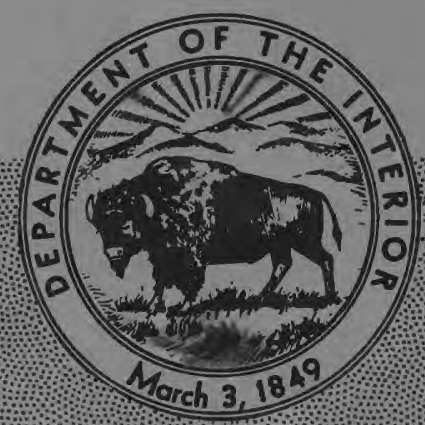

\title{
PRELIMINARY RESULTS OF
}

RADIOMETRIC RECONNAISSANCE OF

PARTS OF THE NORTHWESTERN

SAN JUAN MOUNTAINS

COLORADO

By W. S. Burbank and Charles T. Pierson 

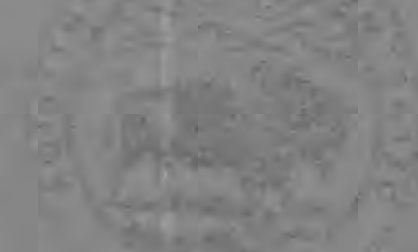

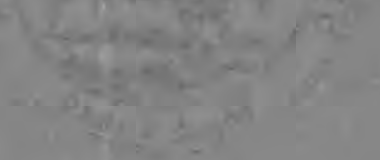
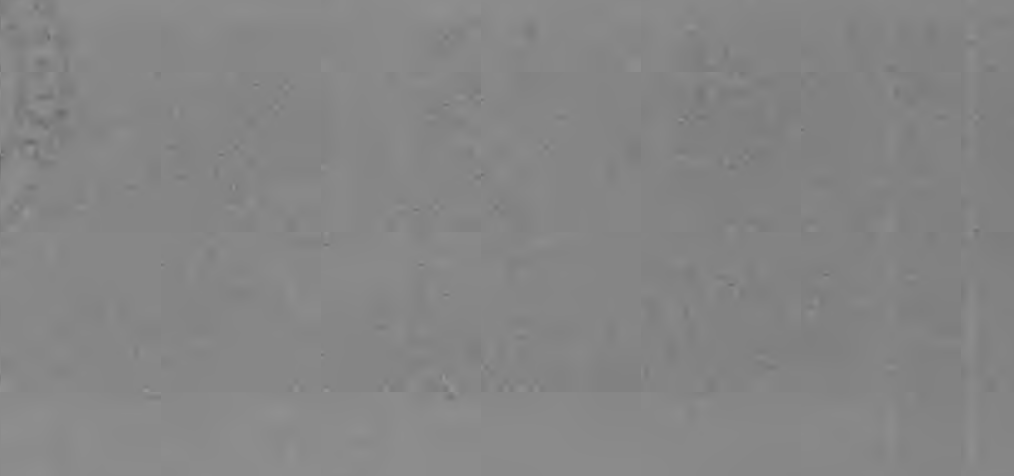

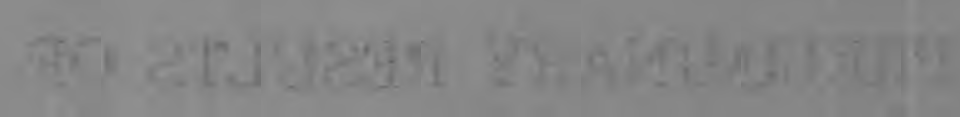

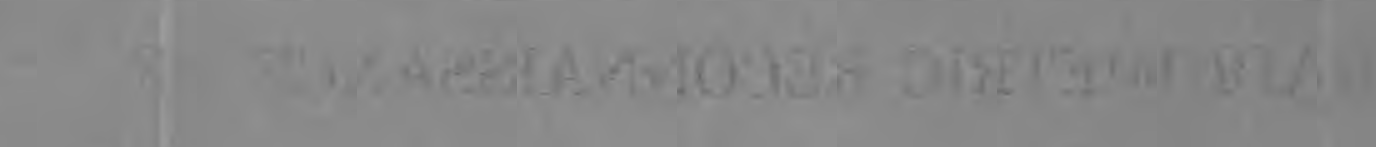

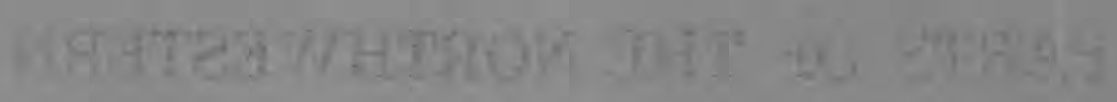

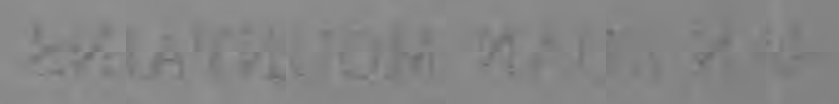

7

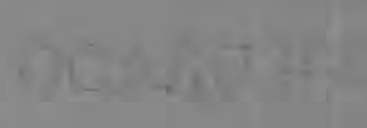

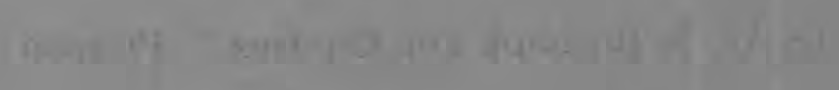


UNITED STATES DEPARTMENT OF THE INTERIOR

Douglas McKay, Secretary

GEOLOGICAL SURVEY

W. E. Wrather, Director

GEOLOGICAL SURVEY CIRCULAR 236

\section{PRELIMINARY RESULTS OF RADIOMETRIC RECONNAISSANCE OF PARTS OF THE NORTHWESTERN SAN JUAN MOUNTAINS, COLORADO}

By W. S. Burbank and Charles T. Pierson

This report concerns work done on behalf of the

U. S. Atomic Energy Commission

and is published with the permission of the Commission

Washington, D. C., 1953

$\overline{\text { Free on application to the Geological Survey, Washington 25, D. C. }}$ 


\title{
PRELIMINARY RESULTS OF RADIOMETRIC RECONNAISSANCE OF PARTS OF THE NORTHWESTERN SAN JUAN MOUNTAINS, COLORADO
}

\author{
CONTENTS
}

Page

Page

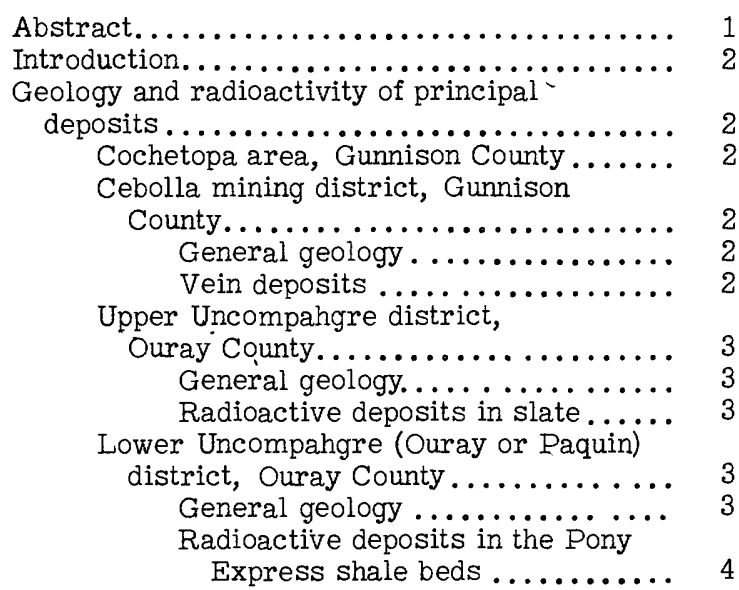

Geology and radioactivity of principal deposits--Continued

Lower Uncompahgre (Ouray or Paquin) district, Ouray County--Continued

Pyritic copper-bearing veins ..... 4

Red Mountain district, Ouray and

San Juan Counties .............. 4

General geology............. 4

Radioactive mineral deposits..... 4

Red Mountain, Animas, and Eureka

districts, San Jyan and Ouray

Counties .................. 5

Ouray Township, hot-spring deposits

of manganese ................. 5

Summary of geologic factors bearing on

uranium concentrations ................ 5

ILLUSTRATIONS

Page

Plate 1. Generalized geologic map showing principal structural areas in the San Juan region, Colorado.. In pocket

2. Geologic map showing structure of the Silverton volcanic center and areas nearby, Ouray, San

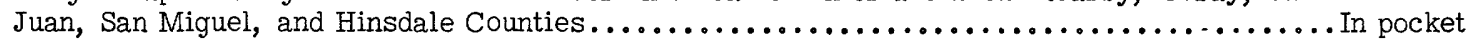

TABLES

Page

Table 1. Location and type of principal deposits examined in relation to age of mineralization, country

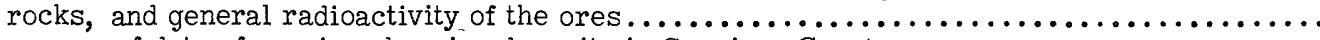

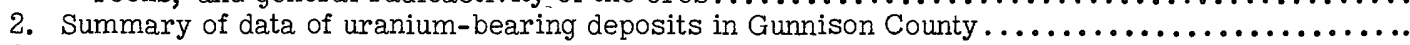

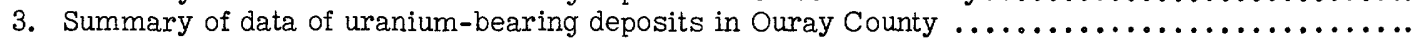

\section{ABSTRACT}

A reconnaissance radiometric survey of parts of the northwestern San Juan Mountains has revealed uranium-bearing ores in several mining districts in Ouray and San Juan Counties, and thorium-bearing veins in southwestern Gunnison County.

Four types of uranium-bearing base-metal and precious-metal sulfide deposits were discovered in the Uncompahgre and Red Mountain districts of Ouray and San Juan Counties. These include: (1) Pyritic impregnations, possibly of early Tertiary or much older age, containing uranium in sheared and drag-folded zones of pre-Cambrian slates; (2) seams and impregnations of pitchblende(?)-bearing ores of early Tertiary age in black bituminous shales of the Pony Express lime- stone member of the Wanakah formation of Jurassic age; (3) pitchblende in late Tertiary chimney deposits in volcanic rocks of Tertiary age, of the Red Mountain district, in association with high-grade copper-silverlead ores and with pyritic ores; (4) sooty pitchblende, also of late Tertiary age, in altered volcanic rocks in pyrite-chalcopyrite seams, small veins, and pyritized rock. The deposits in the pre-Cambrian slates and those in the chimney deposits and minor veins of the volcanic rocks seem to be the most important. At least two ages of uranium mineralization are definitely established, and a third may be possible.

The thorium-bearing deposits in the Cebolla district of Gunnison County are chiefly quartz-carbonate veins with minor base metal and silver minerals in pre-Cambrian mica, chlorite, and greenstone schists. 
They have been subjected to several cycles of erosion and leaching and are jasperized near an early Mesozoic erosion surface on which Jurassic formations rest. The deposits are pre-Jurassic but the exact age of mineralization is not known. The exposed veins are not of economic significance at the present time. Minor quantities of uranium, however, have been leached from the shallow oxidized parts of the veins, and further geochemical studies of the leaching seem desirable. This leaching appears still in progress, and if the rate can be determined, the possibility of finding economic deposits at depth might be established.

Further detailed studies are planned to determine the size and grade of the different types of uranium deposits. Although no deposits of commercial size and grade are known at present, further exploration may be warranted.

\section{INTRODUCTION}

Areas of the northeastern San Juan Mountains, . Colo., covered by radiometric reconnaissance during the field season of 1951, are shown on the attached index map (pl. 1). W. S. Burbank was engaged in this work from July 28 to September 20 and was joined by $\mathrm{C}$. T. Pierson in the Uncompahgre and Red Mountain areas for the period, September 6 to 14. This work was done on behalf of the Division of Raw Materials of the U. S. Atomic Energy Commission.

The districts and types of deposits examined are listed in table 1 giving known or inferred ages of mineralization, country rocks, and the general radioactivity of deposits. Selection of deposits and areas for particular attention was based mostly upon previous investigations of the Geological Survey in this area over a 20-year period. The coverage is not strictly systematic and has not been completed. Some leads to radioactive deposits were obtained from examination of mineral collections.

The general geology of the San Juan Mountain area is best summarized by Cross and Larsen. 1 Plate 1 of this bulletin is of value in showing the general geologic environment of the deposits.

Mineral deposits of the several districts are summarized in the volume Mineral resources of Colorado $^{2}$ issued by the State of Colorado. Plates 27 and 28 of this volume show the structural environment and locations of some of the mines mentioned and are reproduced with modifications as plates 1 and 2 in this report.

\section{GEOLOGY AND RADIOACTIVITY OF PRINCIPAL DEPOSITS}

\section{Cochetopa area, Gunnison County}

A brief reconnaissance of the Cochetopa area of Gunnison County south of the Gunnison River was

\footnotetext{
${ }^{1}$ Cross, C. W., and Larsen, E. S., 1935, A brief review of the of the geology of the San Juan region of southwestern Colorado: U. S. Geol. Survey Bull. 843.

${ }^{2}$ Burbank, W. S., and others, 1947, San Juan mining district, in Mineral resources of Colorado, Colorado Min. Res. Board, Pp. 396439.
}

made along the courses of Cochetopa and Los Pinos Creeks (pl. 1, area 1). The veins are chiefly chloriteand tourmaline-bearing quartz veins containing shoots of chalcopyrite and gold ore. Although reconnaissance of the vein outcrops and mine dumps was done by spot checks, the work indicates a general lack of radioactive materials in veins of this type, which are the typical Gunnison "gold belt" deposits found also in the Cebolla district, described below. The veins occur chiefly in micaceous, chloritic, and hornblendic schists (or greenstones) of pre-Cambrian age. $\mathrm{Hill}^{3}$ regarded the veins as probably of pre-Cambrian age.

One minor occurrence of radioactive jaspery vein matter was found near the southern limit of the pre-Cambrian exposures along Cochetopa Creek. This vein matter occurs along a prominent fault or shear zone and resembles the thorium-bearing radioactive veins of the Cebolla district.

No abnormally radioactive material was found in the overlying Tertiary volcanic rocks of the Los Pinos Creek area.

\section{Cebolla mining district, Gunnison County}

General geology. - The Cebolla district lies on the north flank of the San Juan Mountains south of the Gunnison River (pl. 1, area 2). It is characterized by dissected mesas sloping toward the Gunnison River at an altitude of about 8,500 to 9,000 feet. The preCambrian basement rocks are capped by erosion remnants of the Alboroto rhyolite and latitic breccias of the San Juan Mouritain volcanic rocks. Beneath the volcanic capping there are a few thin remnants of Jurassic sedimentary rocks bordering the Gunnison River. The early Tertiary erosion surface.on which the volcanic rocks rest and the late Paleozoic or early Mesozoic surface on which the Jurassic rocks rest are closely coincident. This is of possible significance with regard to,cycles of erosion and leaching to which the vein deposits have been subjected.

The pre-Cambrian rocks are exposed over large areas between the dissected mesas and in the canyons of the principal streams, the Lake Fork Gunnison River, and Cebolla Creek. They consist of chlorite, mica, and hornblende schists and greenstones, which are intruded by granitic and syenitic rocks and cut by pegmatite dikes and younger volcanic rocks. The granitic and pegmatitic rocks are of pre-Cambrian age, but some dikes and other intrusive rocks may be younger.

Vein deposits. - Two types of vein deposits occur in the Cebolla area besides the pegmatite dikes. They are capped unconformably by Jurassic sedimentary rocks and Tertiary volcanic rocks. The oldest veins are quartz-chlorite and contain copper and gold like those of the Cochetopa area. These are generally nonradioactive although a few minor exceptions were noted. The principal radioactive deposits are quartzcarbonate veins containing minor amounts of pyrite, sphalerite, and galena. Locally the deposits were prospected for silver. The quartz in many veins is typically smoky and crackled and is associated with

\footnotetext{
${ }^{3}$ Hill, J. M., 1909, Gold and silver. -Notes on the economic geology of southeastern Gunnison County, Colo.: U. S. Geol. Survey Bull. 380-A, PP. 21-40.
} 
a gray carbonate gangue of dolomitic or ankeritic aspect. The sulfides and radioactive materials are intergrown with these gangues in exposures of the veins along the valley and canyon walls. On the mesa surfaces the veins are locally much altered to a vericolored jaspery material, which has chiefly replaced the carbonate gangue. The jaspery material retains some of the radioactivity of the original vein matter (table 2, K72). The veins are locally jasperized to depths of 50 to 100 feet beneath the volcanic capping of the mesas. Jasperization was also prevolcanic and presumably related to older Mesozoic or late F'aleozoic erosion surfaces. It may be partly related to hot-spring activity.

Exposures of the veins in the canyons and dissected mesas through a vertical range of 800 to 1,000 feet show that oxidation extended locally to depths of several hundred feet, depending upon local relief and ground-water conditions. Leaching and dispersion of the radioactive material could have taken place during several cycles of erosion since Paleozoic time.

The greater part of the present radioactivity is due to the thorium content of the veins (table 2, K83, $\mathrm{K}-13-1$ ), but conceivably some uranium could have been leached from the veins near the different erosion surfaces. Deposition of postmine radioactive carbonate stalactites indicates that some leaching of uranium disintegration products is still in progress (table 2, $\mathrm{K}-17-4)$. Further chemical research is desirable to form a basis for judging the significance of these occurrences.

The veins are not of economic value at present, but, should appreciable leaching of uranium become established, further testing by deep drilling would be desirable.

Upper Uncompahgre district, Ouray County

General geology. - The upper Uncompahgre district is defined in this report as that part of the Uncompahgre River drainage area south of Ouray and north of the Red Mountain district (pl. 1, area 3, and pl. 2). It lies on either side of the canyon of the Uncompahgre River, which has cut through the rocks of the western flank of the San Juan Mountains exposing the pre-Cambrian basement. Rocks exposed consist of the Uncompahgre formation of pre-Cambrian age, the Paleozoic and Mesozoic sedimentary rocks, and the San Juan tuff and Silverton volcanic series of Tertiary age. At least two ages of base- and preciousmetal mineralization have been recognized-one of early Tertiary age in Mesozoic, Paleozoic, and preCambrian rocks, and another of late Tertiary age in all formations. There is an additional possibility that a third period of mineralization affected only the preCambrian rocks.

The pre-Cambrian Uncompahgre formation is exposed south of Ouray at the edge of the Paleozoic and Mesozoic ancestral San Juan Mountains. In the Uncompahgre canyon the rocks are exposed for a distance of $3 \frac{1}{2}$ miles and through a vertical range of more than a thousand feet. The formation consists of alternate layers of quartzite and black slate from 50 to several thousand feet in thickness. No bottom or top of the series is exposed. The beds are steeply tilted, folded, and thrust-faulted. Crenulations and fracturing of the slate and quartzite beds seem to be mostly, but not entirely, related to these pre-Paleozoic structural features.

The slate bands, as contrasted with the quartzite bands, show moderately high radioactivity throughout their exposures; counter readings of $1 \frac{1}{2}$ to 2 times background are of fairly common occurrence. The widespread radioactivity of the slates and the structural environment of local uranium concentrations are suggestive of an initial pre-Cambrian low-grade concentration, which has been enriched locally by early Tertiary processes of mineralization. (See also "Hot Spring deposits of manganese.")

Radioactive deposits in slate. - Radioactive deposits are found in the sheared and fractured slates near U. S. Highway 550 about midway up the canyon walls in the slate member of the Uncompahgre formation at Bear Creek (pl. 2). Sheared and crenulated zones of slate from several to 10 feet wide range from a few hundredths to roughly one-half percent in uranium or equivalent uranium content (table $3, \mathrm{~K} 33-1$ and K42-1). The higher-grade bands so far located are not over several inches to a foot wide and probably are discontinuous. Continuity of the wider radioactive bands has been established for only about 100 feet laterally and 50 feet vertically, the limits to which reconnaissance examination was carried.

The mineralized slate is moderately to slightly impregnated with pyrite and other metallic minerals; a little lead, copper, zinc, and vanadium are indicated by spectrographic analysis. Fracture surfaces of the slate are slightly stained with iron oxide, and weathered surfaces are locally distinguished by a dull sooty appearance. From limited observation the latter characteristic seems indicative of the outcrops of more highly radioactive slate bodies.

No deposits of commercial importance have been proven, but the local strength of concentrations and general high radioactivity of the slate seem favorable for deposits of significant grade and size.

Quartz or quartz-rhodonite veins and pyritic impregnations of late Tertiary age occur in the slate and quartzite beds. A few such occurrences in fissured and fractured slate checked by the counter proved of negligible radioactivity, generally averaging below bedrock background of the slate nearby. Some of these veins contain base-metal, precious-metal, and tungsten-bearing ores. Investigation of these veins is not completed.

\section{Lower Uncompahgre (Ouray or Paquin) district, Ouray County}

General geology. - The lower Uncompahgre district is defined to include the mineral deposits of early Tertiary age that lie chiefly near and north of Ouray in the Paleozoic and Mesozoic sedimentary rocks (pl. 1, area 4; and pl. 2). These formations were intruded in early Tertiary or Late Cretaceous time by stocks, dikes, sills, and laccolithic bodies of quartz monzonite and related rocks. The laccoliths formed chiefly near the base of the Mancos shale. The domed and altered formations were reduced by erosion to monadnocks during early Tertiary (Eocene?) time 
and were covered unconformably by several thousand feet of volcanic breccia and flows during later Tertiary time. All rocks were again moderately fractured and mineralized in late Tertiary time. Late Tertiary mineral deposits in this district are distant from the main centers of mineralization of this age and are mostly of minor importance.

The early Tertiary deposits ${ }^{4}$ occur as base-metal and precious-metal veins and blanket ore bodies chiefly in rocks of Mesozoic age, including the Dolores formation (Jurassic(?) and Late Triassic), the Entrada sandstone (Late Jurassic), the Wanakah formation (Late Jurassic), the Morrison formation (Late Jurassic), the Dakota sandstone (Cretaceous), and the Mancos shale (Late Cretaceous). The most productive formations are between the Dolores and the base of the Mancos shale, . but a few productive veins cut the Cutler- and Hermosa formations of Permian(?) and Pennsylvanian age. Also, a few ore channels of the manto type are found in the Leadville limestone and Molas formations of Mississippian and Pennsylvanian age.

The veins are generally steep and narrow, but are offset by "rolls" where they pass through alternations of soft shales and harder rocks of nearly horizontal or moderately tilted attitude. At certain horizons, notably in the Morrison and in the breccia and shale units of the underlying Pony Express limestone members of the Wanakah formation, blanket ore bodies may extend a few feet to a few tens of feet laterally from the vein rolls.

Radioactive deposits in the shale beds of the Pony Express limestone member of the Wanakah formation. The most radioactive deposits found in the lower Uncompahgre district lie in the bituminous shaly beds at the base of the Pony Express limestone. These beds were formerly capped by a considerable thickness of nodular gypsum with interstitial limy material (equivalent probably to the Todilto limestone and gypsum members of New Mexico). Destruction of the gypsum bed by leaching during Mesozoic uplift of the mountains resulted in a porous remnant breccia of limy composition, ranging from a feather edge to 10 or 15 feet in thickness. This bed forms a notably porous blanket that was generally favorable for mineral concentrations by filling and replacement.

In the Pony Express mine the blanket ore bodies ranged from a few feet to 50 feet in width and were locally 8 or 10 feet in thickness. Most of this ore, which was not radioactive, has been mined out, but the mineralized walls and shaly floor of the deposits remain. The black bituminous shale at the base is locally replaced and veined by sulfides near the steep veins. In the Pony Express mine the shale contains radioactive material for a strike length of about 400 feet. The content appears generally less than 0.05 percent equivalent uranium (table $3, \mathrm{~K} 30-1$ ), but much of the shale floor is not exposed to observation, and other parts of it away from the main fissures are not appreciably mineralized. The unaltered shale, either in the mines or at exposures several miles north of the district, shows no abnormal radioactivity. It is probable, therefore,

\footnotetext{
${ }^{4}$ Burbank, W. S., 1941, Structural control of ore deposition in the Uncompahgre district, Ouray County, Colo., with suggestions for prospecting: U. S. Geol. Survey Bull. 906-E, pp. 189-265, 1940.
}

that the radioactive material was introduced into the altered shale by the mineralizing solutions.

Radiometric traverses of several mines in this and other sedimentary horizons failed to reveal appreciable concentrations of uranium. Two mines, the Senorita and Newsboy in the Pony Express limestone member and the Entrada sandstone, showed notable concentrations of radon(?) gas in the old blanket stopes and drifts (local readings as much as 0.3 or 0.4 milliroentgen per hour with a Geiger counter). The source of the gas was not found, but obviously it could travel far in the porous blanket.

Only mines east of the Uncompahgre valley were examined; some further reconnaissance work seems desirable west of the valley.

Pyritic copper-bearing veins. - Some veins in the Cutler and Hermosa formations near the center of the mineralized area exhibit slight radioactivity anomalies. They are relatively high-temperature replacement veins and narrow fracture fillings containing chalcopyrite and minor gold. Only spot checks have been made.

$$
\underline{\text { Ouray and San Juan Counties }}
$$

General geology. - The Red Mountain district lies in the Tertiary volcanic rocks along the western border of the Silverton cauldron subsidence (pl. 1, area 5; and' pl. 2). It is characterized by strong hydrothermal alteration of the volcanic rocks and by the principal occurrences of ore deposits in chimneylike forms. The more productive chimney deposits lie along a milewide belt several miles in length, with a N. $25^{\circ}-30^{\circ} \mathrm{E}$. trend. The ore belt is bordered on the west by an arcuate belt of faults, a mile or two wide. This fault belt forms the western border of the downfaulted cauldron blocks.

The fault and ore belts are intruded by numerous volcanic plugs and breccia necks, which with the intense alteration indicate that the mineralized area represents the roots of a former surface area of intense volcanic, fumarolic, and hot-spring activity. The depth at which the ore deposits was formed is estimated at close to a mile below the original surface.

Most of the higher-grade chimney deposits of ore have a maximum vertical range of 800 to 1,000 feet: They are commonly zoned vertically, with lead-silver ores in the upper parts, rich copper-silver ores in the middle, and pyritic copper ores or relatively barren pyrite at depth. This is not invariable, as many exceptions to the ideal zoning are evident in local details of the ore bodies. Copper occurs in sulfosalts of antimony, arsenic, and silver, and as stromeyerite, chalcocite, chalcopyrite, covellite, and enargite. The local abundance of enargite, particularly in the pyritic ores, also distinguishes these deposits from the normal vein deposits in the Telluride and Sneffels districts beginning immediately northwest of the fault belt (pl. 2).

Radioactive mineral deposits. - Two types of radioactive mineral occurrences were found in the Red Mountain district. One is in association with the chimney deposits and the other in association with pyritic veins along the edge of the fault belt bordering the cauldron subsidence. 
The higher-grade copper-lead-silver fragments of chimney ores found on dumps almost throughout the length of the belt contain associated radioactive material, presumably as pitchblende (table $3, \mathrm{~K} 35-1$ to $\mathrm{K} 39-2$, etc.). Also, some pyritic ore is moderately radioactive (table 3 , $\mathrm{K} 39-2, \mathrm{~K} 36-1, \mathrm{~K} 36-2$ ). The locations of most of these occurrences have not been established because the ore shoots are mostly mined out. At a few scattered localities, however, radiometric checks of minor surfaces showings and fissures confirm the presence of radioactive material in the ore and altered rock nearby (table 3, K34-1). The highest-grade material found on dumps may be of the order of 1 percent or more of uranium or equivalent uranium (table $3, \mathrm{~K} 35-2$ ). The very sparse distribution of such ore on the dumps indicates either an erratic occurrence or that the early miners carefully sorted and saved these richer ores with which the uranium appears associated.

Further investigation of chimney ore bodies in place will be necessary to establish the vertical and lateral limits of uranium-bearing ores. Evidence gathered so far seems to indicate that ore material similar to that found in the better-grade pockets shows the highest radioactivity. For this reason a surface radiometric survey of the mineral belt has been recommended as one of the first steps in the further study of this district.

The second type of radioactive deposit was found at the edge of the fault belt in an active mining prospect, the Larson property, west of the northern end of the main chimney ore belt (table 3 and pl. 2). It consists of pyritic veins and impregnations in a zone of intensely fractured and altered rocks. A crosscut tunnel exposes several hundred feet of ground cut by numerous northto northeast-trending pyrite veins in pervasively pyritized and altered country rock. The altered belt is radioactive almost throughout, with counter readings in the center of the crosscut ranging from 0.05 to 0.12 milliroentgen per hour. A sample of one small pyrite vein with minor chalcopyrite and visible sooty pitchblende contained 0.034 percent uranium (table 3 , $\mathrm{K} 40-1$ ).

Veins in the same belt that contained quartz gangue either with pyrite or base-metal ores were radiometrically negative, indicating that the open fissures were not favorable loci for the segregation of uranium ore. The probable causes for this will be discussed later under "Summary of geologic factors bearing on uranium deposits."

Red Mountain, Animas, and

Eureka districts, San Juan and Ouray Counties

The normal base-metal and precious-metal ore veins in the Red Mountain, Animas, and Eureka districts of Ouray and San Juan Counties generally show no radiometric anomalies. Checking of the numerous veins is far from complete. Spot checks of a number of typical veins made during the present reconnaissance and checks of veins and dumps during previous field seasons have shown only sparsely distributed minor occurrences of radioactive material. A few of the larger mining companies have Geiger counters and report similar experiences.
The normal vein deposits are essentially characterized by abundant gangue of quartz, rhodonite, rhodochrosite, and barite, and by local gangues of fluorite, adularia, and various calcitic or ankeritic carbonates. In this respect they differ from the typical radioactive ore occurrences described above.

\section{Ouray Township, hot-spring deposits of manganese}

Several recent radioactive hot-spring deposits occur in Ouray Township at the northern edge of the pre-Cambrian exposures in the Uncompahgre canyon. They are located near or within a few thousand feet of a major fault separating pre-Cambrian and Paleozoic rocks. Some deposits of calcareous tufa and of manganese and iron oxides that were deposited below ancient spring sites lie beneath glacial gravels of Pleistocence age. One such deposit at the northern edge of town was partly mined in recent years for its manganese content. According to reports the ore contained some tungsten, and unmined remnants of it are moderately radioactive. Chemical analyses have not been completed, but from previous tests of the ore it is suspected that the radioactive material may be chiefly radium or its products. No deposits of economic value for their uranium content are known, and it seems unlikely that such deposits exist.

The deposits are of interest, however, because several mineral-bearing veins nearby in the Paleozoic limestones from which the springs now emerge do not contain radioactive material. The only radioactive rocks cropping out south of the springs are the slates of the Uncompahgre formation. Because these are known to contain uranium concentrations and underlie the hot-spring area at moderate depths, it is reasonable to believe that the slate beds may have been the source of the radioactive material in the spring waters. The reason for the presence of radioactive precipitates in. some deposits and not in others are not clear, although iron oxides are known to have some effect in precipitating radioactive ores. It is also possible that evaporation of the spring waters at temperatures well above those of the recent springs may have been a factor.

\section{SUMMARY OF GEOLOGIC FACTORS BEARING ON URANIUM CONCENTRATIONS}

The thorium-bearing veins of the Gunnison area contain only minor uranium, and further discussion of these will not be undertaken in this report. Some research on the chemistry of such deposits and of the present-day leaching of uranium appears desirable.

The most significant uranium occurrences economically are those in the slate beds of the Uncompahgre formation south of Ouray, the two types'found in the Red Mountain area, and the minor occurrences north of Ouray.

These deposits have certain common geologic and environmental characteristics. The most notable features are (1) the uranium is typically associated with ores having only sparse intergrown gangue minerals, in contrast with the nonuraniferous ores of the 
principal vein deposits, and (2) the ores occur chiefly in chimneys, veins, or disseminations that were not connected by open conduits to major fissures and to the ancient land surfaces.

The latter conclusion is based upon detailed studies of these deposits made before the present reconnaissance and is supported by the following evidence. Geologic reconstruction of the conditions of ore deposition during the early Tertiary period of mineralization indicates that many veins of this age were formed beneath thick blankets of marine shales. In some places these shales were penetrated by major breaks and intrusive bodies, but at others the oreforming solutions were forced to take lateral paths beneath the semipermeable shale coverings before gaining access to surface outlets.

By contrast, most of the veins of the late Tertiary period of mineralization, which took place after erosion of the Upper Cretaceous shales, formed in strong fisfures that extended certainly to the surfaces of the volcanic plateaus or to shallow ground-water blankets.

The chimney deposits and certain associated minor vein deposits are an exception to the general conditions of the late Tertiary ore deposition. These deposits were sealed from direct outlets to the surface by silicified envelopes of fine-textured quartz and by semipermeable walls of softened and pervasively altered rocks. The ores were accordingly deposited in "deadend" structural pockets and leached caves by repeated distillation and vaporization of ore solutions in a relatively high-temperature semisealed environment. Only the more volatile constituents escaped with the vapors or by diffusion through semipermeable wallrock seals.

Under these semisealed environments all relatively nonvolatile metals were concentrated and deposited in the structural pockets or were disseminated by replacement in the immediately enclosing wall roaks. It is to be expected that uranium would not readily escape from such an environment.

Many gangue minerals that are common elsewhere are either absent or sparse in the sulfide ores of the Red Mountain district. This has been recognized for many years by miners as particularly characteristic of the chimney ore bodies of the Red Mountain area. An additional characteristic is the abundance of arsenic- and antimony-bearing ore minerals in such deposits as compared to the normal vein deposits. Enargite is a common ore of copper in the chimneys but is rarely found in the normal ganguerich vein deposits a few thousand feet away. Thus even arsenic and antimony are concentrated by the same selective process that segregated the uranium.

If it is assumed, accordingly, that semisealed environment favor the retention of relatively soluble uranium compounds in sulfide ores, the different occurrences found in the northwestern San Juan region fall into a reasonable pattern. The Red Mountain chimney deposits and the sheared and minutely fractured pre-Cambrian slates form the more favorable environments. The open strong veins with notable quantities of gangue in both areas are conspicuously lacking in uranium concentrations. In the fault belt northwest of Red Mountain the larger gangue-bearing veins, even within a few tens of feet of the pyritic pitchblende seams and disseminations, generally show counter readings below normal background.

These environments are of course transitional in their characteristics, and it may be difficult in given occurrences to recognize the semisealed environments. The chimney deposits are generally recognizable from the typical wall-rock alteration with siliceous envelopes and the abundant hydrothermal clays and associated minerals in the surrounding altered rocks (dickite, montmorillonite-beidelite group of clays, diaspore, alunite, zunyite, and others). Pervasive pyritization is common in certain semipermeable environments such as characterize the faulted belts bordering the Red Mountain district on the west.

It is thought that the abundant gangues of the vein deposits in the volcanic rocks were derived from selective leaching of the wall rocks under conditions of repeated fracturing and release of pressure. Such conditions are naturally met most commonly in the larger open fissures, many of which show crustification and other evidence of numerous reopenings. In contrast, mutual complex intergrowths are mare characteristic of the chimney sulfide ores.

The chemical and physical conditions that are thought to have resulted in the formation of the chimney ore bodies cannot be reviewed in further detail in this brief summary. A more extended discussion has been published ${ }^{5}$ and a thermodynamic analysis of the conditions of mineralization is in preparation.

\footnotetext{
${ }^{5}$ Burbank, W. S., 1951, Problems of wall-rock alteration in shallow volcanic environments, in Colorado School of Mines Quart., vol. 45 (75th Anniversary Volume), No. 1B, Applied Geology, pp. 286-319.
} 


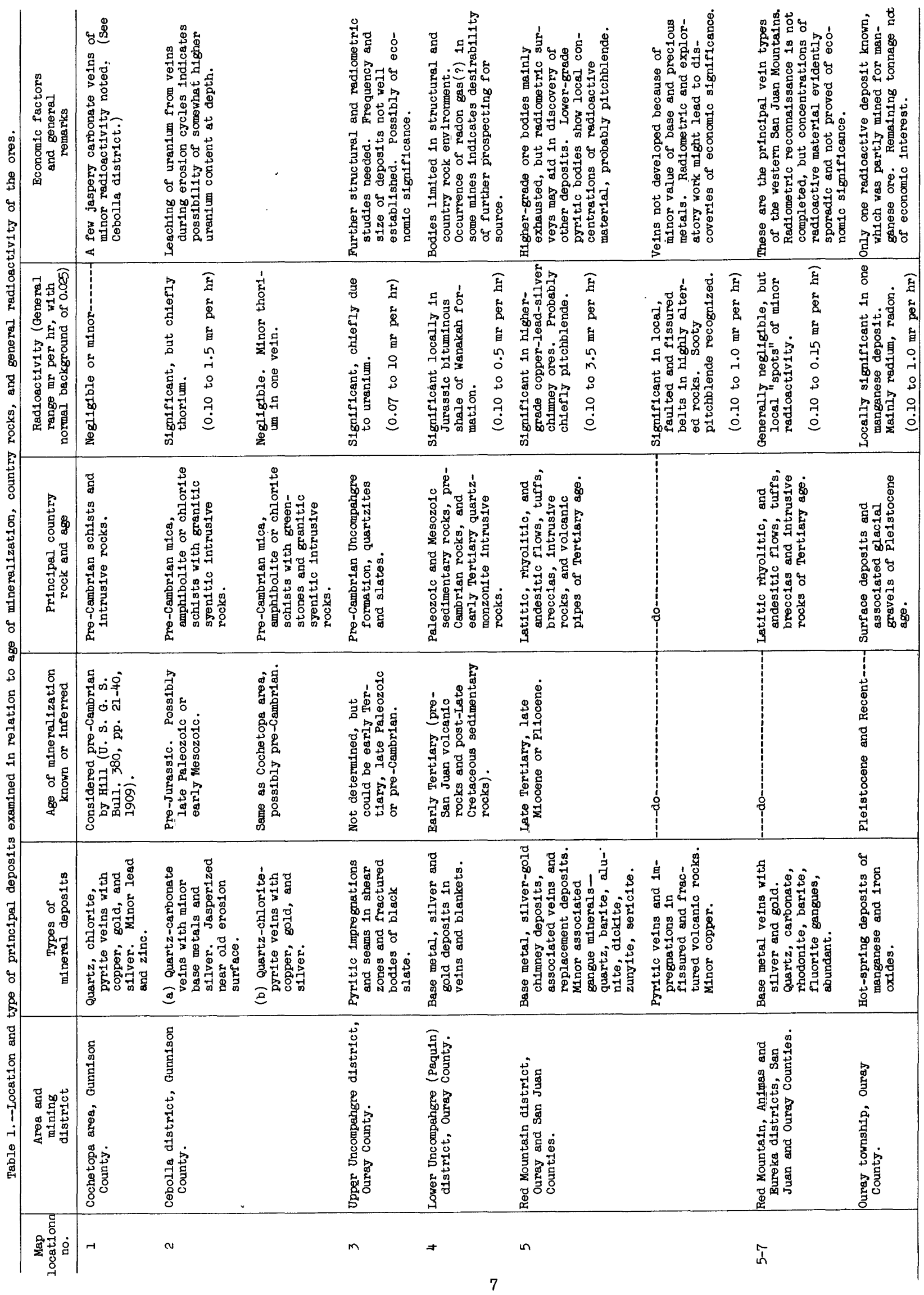




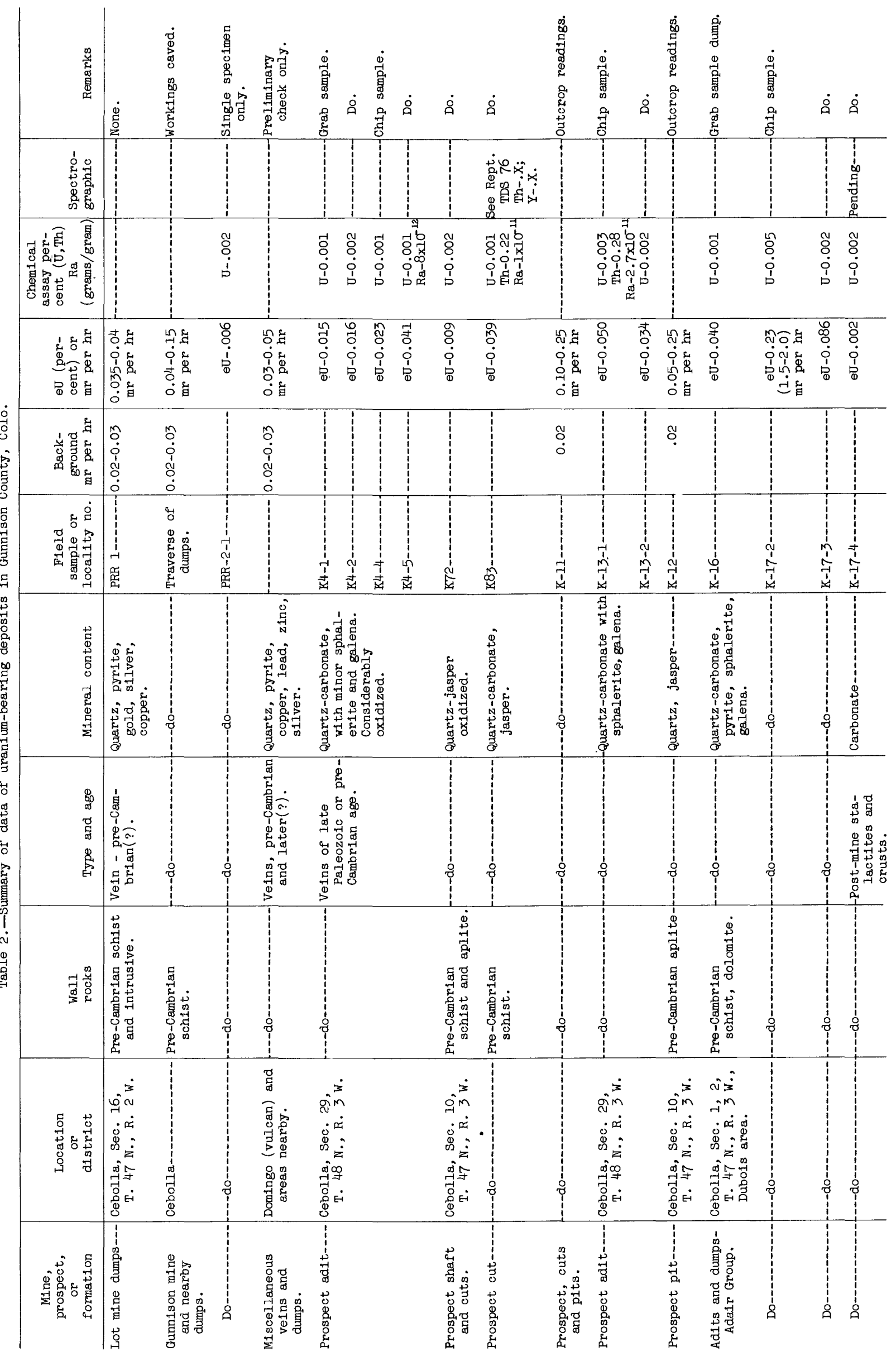




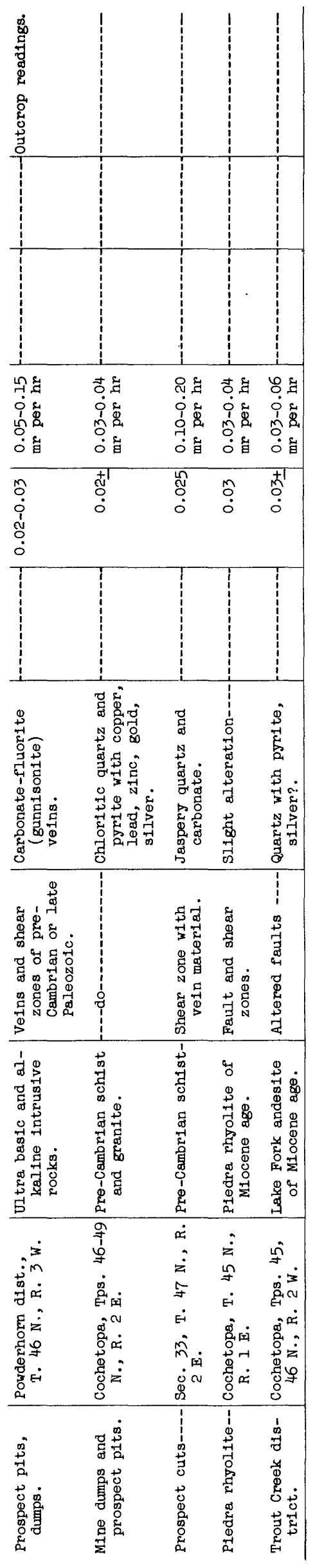




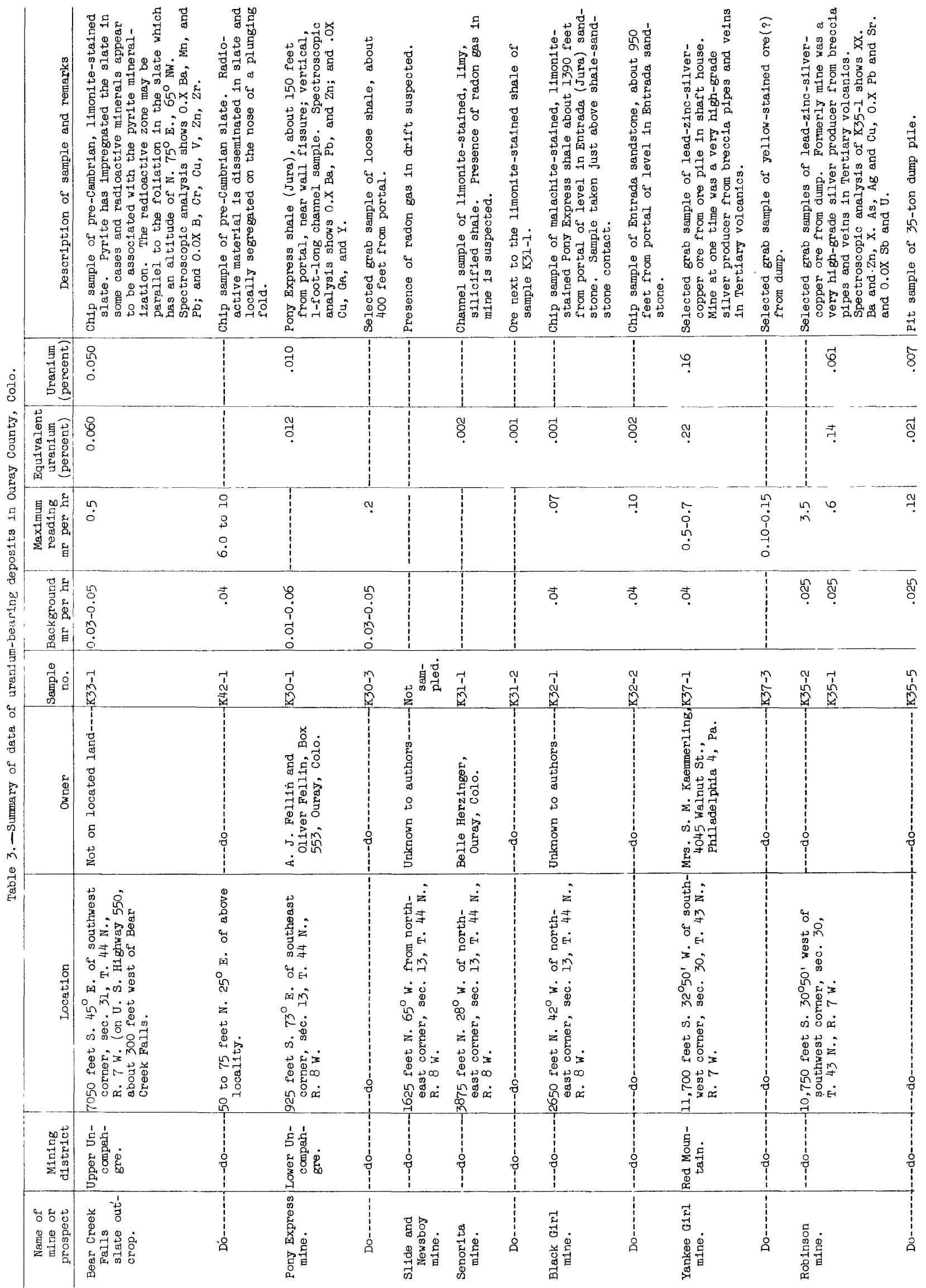



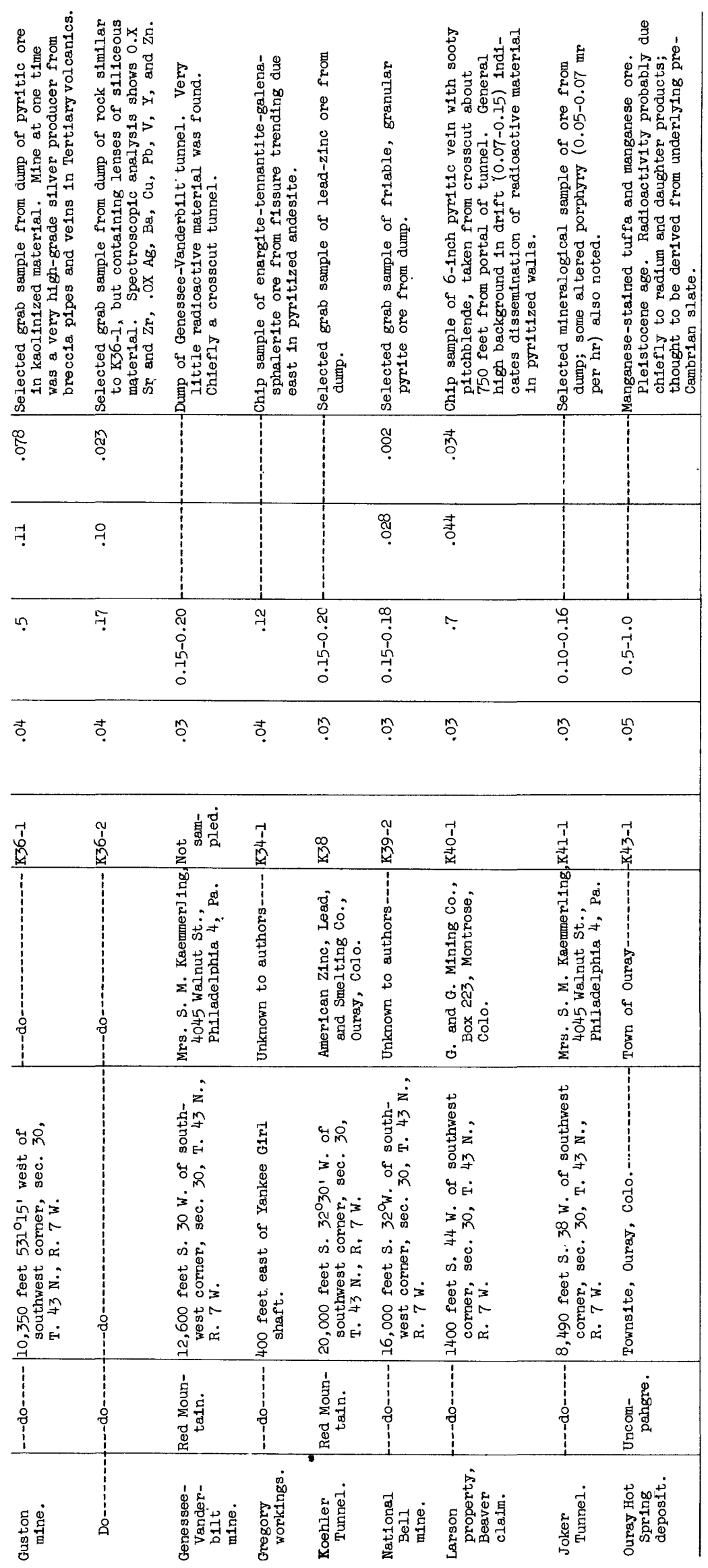